\title{
DUKUNGAN KELUARGA DALAM PEMENUHAN KEBUTUHAN MAKAN PENDERITA TBC PARU DI RUMAH
}

\author{
Triana Setijaningsih ${ }^{1}$, Nunung Rahayu Ningsih ${ }^{2}$, Suprajitno $^{3}$ \\ 1,2,3 Jurusan Keperawatan, Poltekkes Kemenkes Malang \\ *E-mail: trianasetijaningsih@gmail.com
}

\begin{abstract}
Abstrak
Dukungan keluarga merupakan bantuan nyata yang dipandang oleh anggota keluarga sebagai sesuatu yang dapat diakses atau diadakan untuk keluarga, meliputi dukungan informasional, dukungan instrumental, dukungan penilaian dan dukungan emosional. Tujuan penelitian ini menggambarkan dukungan keluarga dalam pemenuhan kebutuhan makan penderita TBC Paru di rumah. Desain penelitian menggunakan rancangan deskriptif. Populasi penelitiannya keluarga dengan salah satu anggota keluarganya menderita TBC Paru, jumlah sampel 44 keluarga, diambil menggunakan teknik sampling jenuh. Instrumen yang digunakan untuk pengumpulan data adalah kuesioner. Hasil penelitian menunjukkan dukungan keluarga dalam pemenuhan kebutuhan makan penderita TBC Paru di rumah dengan kategori supportif sebanyak 59,1\% (26 keluarga) dan dengan kategori nonsupportif sebanyak 40,9\% (18 keluarga). Hal tersebut ditunjukkan dengan kurangnya pengalaman keluarga dalam merawat penderita tuberkulosis dan kurangnya informasi yang diterima keluarga tentang nutrisi bagi penderita tuberkulosis. Pemegang program TB di UPTD Puskesmas diharapkan dapat meningkatkan pendidikan kesehatan tentang pentingnya nutrisi bagi penderita tuberkulosis.
\end{abstract}

Kata kunci: dukungan, keluarga, tuberkulosis, nutrisi

\begin{abstract}
Family Support In Nutrition Care For Patients With Tuberculosis At Home. Family support is a real help that family members see as being accessible, including informational support, instrumental support, assessment support and emotional support. The purpose of this research is describes the family support in nutrition care for patients with tuberculosis at home working area UPTD Puskesmas Blitar. The research design used descriptive. The population is family with one of the family is a patientwith tuberculosis, the sample is 44 family using total sampling technique, which used a questionnaire instrument. The result of the research showed that family support in nutrition care for patients with tuberculosis at home with supportif category is 59\% (26 family) and nonsupportif category is $40,9 \%$ (18 family). This is shown by the lack of family experience in treating tuberculosis sufferers and lack of information received by families about nutrition for tuberculosis patients. The healthcare workers that manage Tuberculosis Program in UPTD Puskesmas are expected to improve health education about the importance of nutrition for tuberculosis patients.
\end{abstract}

Keywords: support, family, tuberculosis, nutrition 


\section{Pendahuluan}

Tuberkulosis adalah infeksi penyakit menular yang disebabkan oleh Mycobacterium tuberculosis, suatu basil aerobik tahan asam yang ditularkan melalui udara (Asih, 2004). Menurut Djojodibroto (2009), diperkirakan bahwa sepertiga penduduk dunia pernah terinfeksi kuman $M$. Tuberkulosis.

Menurut Asih (2004), hampir semua kasus infeksi tuberkulosis didapat melalui inhalasi partikel kuman yang cukup kecil. Seseorang yang terinfeksi tuberkulosis dapat menularkan kepada 10-15 orang, 10\% di antaranya akan berkembang dan menjadi penderita tuberkulosis. Faktor yang mempengaruhi kemungkinan seseorang menjadi sakit tuberkulosis adalah daya tahan tubuh yang rendah, gizi buruk, dan sedang menderita penyakit lainnya (Cahyono, 2014).

Kebanyakan individu dengan TB aktif mengalami penurunan berat badan dan beberapa diantaranya menunjukkan tandatanda kekurangan nutrisi. Dalam Nutritional care and support for patients with tuberculosis disebutkan bahwa berkurangnya berat badan dapat menjadi indikasi keparahan TB (WHO, 2013).

Masukan nutrisi yang tidak adekuat pada penderita tuberkulosis dapat diakibatkan oleh gaya hidup pasien, kurang pengetahuan tentang nutrisi yang adekuat dan perannya dalam pemeliharaan kesehatan, keletihan akibat batuk berat, pembentukan sputum, nyeri dada, atau status kelemahan secara umum (Smeltzer \& Bare, 2002).

Untuk menghadapi efek dari faktor tersebut, maka diperlukan adanya bantuan dan dukungan dari orang terdekat, khususnya keluarga yang tinggal serumah dengan penderita tuberkulosis dalam memenuhi kebutuhan makannya. Dukungan keluarga akan benar-benar bisa dirasakan penderita apabila ada keter- libatan dan perhatian yang mendalam dari keluarga. (Smeltzer \& Bare, 2002).

Cobb dalam Smeltzer \& Bare (2002) mendefinisikan dukungan sebagai rasa memiliki informasi terhadap seseorang atau lebih dengan tiga kategori yaitu yang pertama membuat orang percaya bahwa dirinya diperhatikan atau dicintai, yang kedua menyebabkan seseorang merasa bahwa dirinya dianggap dan dihargai, dan yang ketiga membuat seseorang merasa dirinya merupakan bagian dari jaringan komunikasi. Dengan adanya dukungan keluarga maka keberhasilan penyembuhan dan pemulihan klien tuberkulosis akan meningkat. Dukungan keluarga dapat berupa dukungan informasional, dukungan penilaian, dukungan emosional, dan dukungan instrumental (Setiadi, 2008). 
Di Kota Blitar pada tahun 2016, Metode

tercatat jumlah kasus penderita tuberkulosis sebanyak 48 orang yang sedang menjalani program pengobatan di tiga wilayah kecamatan diantaranya di Puskesmas Kecamatan Sukorejo sebanyak 20 penderita, di Puskesmas Kecamatan Sananwetan sebanyak 17 penderita dan di Puskesmas Kecamatan Kepanjen Kidul terdapat sebanyak 11 penderita.

Dari hasil studi pendahuluan yang peneliti lakukan pada tanggal 27 Desember 2016 di Puskesmas Kota Blitar, peneliti mewawancarai 5 keluarga dan diketahui 3 diantaranya memberikan dukungan instrumental dan dukungan emosional yang kurang dalam pemenuhan kebutuhan makan penderita tuberkulosis di rumah. Terdapat keluarga yang tidak menyediakan makanan tambahan seperti buah, susu, atau suplemen karena tidak tahu apakah makanan tersebut boleh dikonsumsi bagi penderita tuberkulosis, terdapat keluarga yang hanya menyediakan makanan saja tetapi kurang memberikan motivasi dan perhatian saat penderita mengkonsumsi makanannya.

Berdasarkan fenomena dan uraian di atas, peneliti tertarik untuk meneliti tentang gambaran dukungan keluarga dalam pemenuhan kebutuhan makan penderita TBC di rumah.
Desain dalam penelitian ini adalah penelitian deskriptif. Populasinya adalah keluarga dengan salah satu anggota keluarganya menderita TBC Paru dengan sampel sebesar 44 keluarga, diambil menggunakan teknik sampling jenuh. Instrumen yang digunakan untuk pengumpulan data adalah kuesioner.

\section{Hasil}

\section{Karakteristik responden}

Lebih dari setengah keluarga berusia 41-60 tahun yaitu sebanyak 52\% (23 keluarga). Seluruh keluarga penderita tuberkulosis paru beragama Islam yaitu sebanyak 100\% (44 keluarga). Sebagian besar keluarga penderita tuberkulosis paru berpendidikan SMA yaitu sebanyak $75 \%$ (33 orang). Lebih dari setengah keluarga penderita tuberkulosis paru bekerja sebagai wiraswasta yaitu sebanyak $57 \% \quad(25$ keluarga).

Hampir setengah keluarga penderita tuberkulosis paru memiliki hubungan kekeluargaan dengan penderita sebagai istri yaitu sebanyak 36\% (16 keluarga).

Lebih dari setengah keluarga penderita tuberkulosis paru memiliki penghasilan 1.000.000-2.000.000 rupiah per bulan sebanyak 57\% (25 keluarga). Lebih dari setengah penderita tuberkulosis paru mengalami penurunan berat badan sejak 3 
bulan terakhir yaitu sebanyak $66 \%$

keluarga). Lebih dari setengah penderita tuberkulosis paru mengalami penurunan berat badan sebanyak 3-6 kg yaitu sebanyak $60 \%$ (18 keluarga).

Tabel 1. Karakteristik pengalaman keluarga merawat penderita tuberkulosis di UPTD Puskesmas Kota Blitar, Juni 2017 (n=44)

\begin{tabular}{lcc}
\hline $\begin{array}{c}\text { Pengalaman } \\
\text { merawat }\end{array}$ & Frekuensi & Prosentase (\%) \\
\hline Memiliki & 5 & $11 \%$ \\
Tidak & 39 & $89 \%$ \\
\hline
\end{tabular}

Berdasarkan tabel 1 diatas hampir seluruh keluarga penderita tuberkulosis paru tidak memiliki pengalaman merawat pendeita tuberkulosis yaitu sebanyak $89 \%$ (39 keluarga).

Tabel 2. Dukungan Keluarga Penderita Tuberkulosis secara umum di UPTD Puskesmas Kota Blitar, Juni (2017)

\begin{tabular}{clcc}
\hline No & $\begin{array}{c}\text { Dukungan } \\
\text { Keluarga }\end{array}$ & Frekuensi & $\begin{array}{c}\text { Prosenta } \\
\text { se (\%) }\end{array}$ \\
\hline 1 & Supportif & 26 & 59.1 \\
\hline 2 & Nonsupportif & 18 & 40.9 \\
\hline & Jumlah & 44 & 100.0 \\
\hline
\end{tabular}

Berdasarkan tabel 2 diatas menunjukkan bahwa lebih dari setengah dukungan keluarga yang diberikan untuk penderita tuberkulosis adalah supportif dan kurang dari setengah dukungan keluarga yang diberikan untuk penderita tuberkulosis adalah nonsupportif.
Tabel 3. Jenis dukungan keluarga dalam pemenuhan kebutuhan makan penderita TBC paru di rumah wilayah UPTD Puskesmas Kota Blitar, Juni $(n=44)$

\begin{tabular}{lcc}
\hline \multicolumn{1}{c}{ Jenis dukungan } & Supportif & Non supportif \\
\hline Instrumental & $48 \%$ & $52 \%$ \\
Informasional & $57 \%$ & $43 \%$ \\
Emosional & $45 \%$ & $55 \%$ \\
Penilaian & $55 \%$ & $45 \%$ \\
\hline
\end{tabular}

Berdasarkan tabel 3 diatas menunjukkan bahwa lebih dari setengah keluarga supportif dalam memberikan dukungan informasional (29 keluarga) dan dukungan penilaian (24 keluarga) serta lebih dari setengah keluarga nonsupportif dalam memberikan dukungan instrumental (23 keluarga) dan dukungan emosional (24 keluarga).

\section{Pembahasan}

Berdasarkan hasil penelitian diperoleh data dukungan keluarga sebanyak 59,1\% (26 keluarga) dalam kategori supportif, artinya keluarga mendukung dalam pemenuhan kebutuhan makan penderita TBC Paru di rumah dan sebanyak 40,9\% (18 keluarga) dalam kategori nonsupportif, artinya keluarga tidak mendukung dalam pemenuhan kebutuhan makan penderita TBC Paru di rumah. Dukungan keluarga dengan kategori supportif ini berkaitan dengan sebanyak $75 \%$ (33 keluarga) berpendidikan SMA dan 2,3\% (1 keluarga) berpendidikan terakhir Perguruan Tinggi. 
Menurut Mubarak, dkk (2007) bahwa makin tinggi pendidikan seseorang maka makin mudah pula bagi mereka untuk menerima informasi, dan makin banyak pula pengetahuan yang mereka miliki.

Peneliti berpendapat bahwa pendidikan merupakan suatu proses pembelajaran yang dapat meningkatkan pengetahuan dan menambah wawasan. Semakin tinggi tingkat pendidikan seseorang maka pengetahuan dan wawasan yang dimiliki pun bertambah luas serta semakin mudah pula dalam menerima ilmu dan informasi baru. Selain itu, lebih dari setengah keluarga penderita tuberkulosis paru memiliki penghasilan 1.000.0002.000 .000 rupiah per bulan sebanyak $57 \%$ (25 keluarga).

Berdasarkan hasil penelitian Julianti (2007) dalam Manalu (2010), bahwa keluarga yang mempunyai pendapatan yang lebih mampu untuk menjaga kebersihan lingkungan rumah tangganya, menyediakan air minum yang baik, membeli makanan yang jumlah dan kualitasnya memadai bagi keluarga mereka, serta mampu membiayai pemeliharaan kesehatan yang mereka perlukan. Dengan demikian bertambahnya pengetahuan dan semakin tingginya penghasilan keluarga dapat membantu menentukan tindakan yang tepat dalam mendukung penderita tuberkulosis untuk memenuhi kebutuhan makan sehari-hari sehingga tingkat kesembuhan akan meningkat. Dukungan keluarga dengan kategori nonsupportif ini berkaitan dengan kurangnya kemampuan dan pengalaman keluarga dalam merawat anggota keluarga yang sakit ditunjukkan dengan hasil penelitian yang menunjukkan sebanyak $88,6 \%$ (39 keluarga) tidak memiliki pengalaman merawat anggota keluarga yang menderita tuberkulosis.

Menurut Friedman dalam Setiadi (2008), dukungan keluarga dibagi menjadi dukungan instrumental, dukungan informasional, dukungan penilaian/ penghargaan, dan dukungan emosional. Berdasarkan hasil penelitian, jenis dukungan keluarga ditinjau dari tingkatan yang paling supportif adalah dukungan informasional diikuti dukungan penilaian, dukungan instrumental dan dukungan emosional.

Salah satu ciri-ciri dukungan keluarga adalah informatif. Menurut House (Smet, 1994) dalam Setiadi (2008) informatif adalah bantuan informasi yang disediakan agar dapat digunakan oleh seseorang dalam menanggulangi persoalan-persoalan yang dihadapi, meliputi pemberian nasehat, pengarahan, ide-ide atau informasi lainnya yang dibutuhkan dan informasi ini dapat disampaikan kepada orang lain yang mungkin menghadapi persoalan yang sama atau hampir sama. 
Dalam penelitian ini menunjukkan bahwa dukungan informasional dalam kategori supportif sebanyak 56,8\% (25 keluarga) dan dalam kategori nonsupportif sebanyak 43,2\% (19 keluarga). Dukungan informasional dalam kategori nonsupportif ini dibuktikan dengan keluarga yang jarang memberikan informasi kepada penderita tuberkulosis bahwa asupan makanan bergizi dapat meningkatkan kesehatan dan penyembuhan penyakit sebanyak 27\% (12 keluarga), keluarga jarang mencari informasi mengenai makanan yang baik dikonsumsi oleh penderita $\mathrm{TBC}$ selama pengobatan lewat buku, majalah, TV atau tenaga kesehatan sebanyak $39 \% \quad(17$ keluarga). Teori Caplan dalam Friedman (1998) menyebutkan bahwa saran, sugesti, informasi dapat digunakan dalam mengungkapkan suatu masalah. Manfaat dari dukungan informative yang diberikan oleh keluarga kepada penderita tuberkulosis ini dapat menekan munculnya stres yang ditimbulkan akibat pengobatan yang berlangsung lama (minimal enam bulan) karena informasi yang diberikan dapat memberikan semangat kepada penderita.

Peneliti berpendapat bahwa dukungan informatif meliputi bantuan yang diberikan keluarga dalam memberikan dan mencari informasi tentang pentingnya asupan makanan bergizi bagi kesembuhan penyakit. Hasil wawancara yang peneliti lakukan dengan keluarga menunjukkan lebih dari setengah keluarga pada saat mengantar penderita mengambil obat di Puskesmas tidak pernah mencari informasi mengenai pemenuhan kebutuhan nutrisi penderita tuberkulosis, selain itu petugas kesehatan hanya memberikan pendidikan kesehatan tentang nutrisi penderita tuberkulosis pada saat pertama kali penderita menjalani pengobatan. Apabila informasi yang diterima keluarga dari petugas kesehatan kurang akan menyebabkan penderita tuberkulosis tidak dapat memenuhi kebutuhan nutrisi dengan baik sehingga dapat meningkatkan tingkat keparahan tuberkulosis dan mengurangi tingkat penyembuhan penyakit.

Caplan dalam Friedman (1998) menerangkan bahwa dukungan keluarga meliputi dukungan instrumental, yaitu keluarga merupakan sebuah sumber pertolongan praktis dan konkrit. Bantuan instrumental bertujuan untuk mempermudah seseorang dalam melakukan aktifitasnya berkaitan dengan persoalanpersoalan yang dihadapinya, atau menolong secara langsung kesulitan yang dihadapi, misalnya dengan menyediakan peralatan lengkap dan memadai bagi penderita, menyediakan obat-obat yang dibutuhkan dan lain-lain.

Berdasarkan hasil penelitian menunjukkan bahwa dukungan instrumental 
dalam kategori supportif sebanyak $47,7 \%$

(21 keluarga) dan dalam kategori nonsupportif sebanyak 52,3\% (23 keluarga).

Dukungan instrumental dalam kategori nonsupportif ini ditunjukkan dengan sebanyak 39\% (17 keluarga) keluarga jarang menyiapkan suplemen tambahan seperti vitamin atau tablet tambah darah untuk penderita tuberkulosis serta sebanyak 52\% (23 keluarga) sering memberikan makanan yang dapat memicu batuk. Dukungan instrumental yang nonsupportif ini didukung dengan kurangnya pengalaman merawat anggota keluarga yang menderita tuberkulosis ditunjukkan dengan hasil penelitian yang menunjukkan sebanyak 88,6\% (39 keluarga).

Peneliti berpendapat bahwa dukungan instrumental meliputi menyediakan makanan yang dianjurkan seperti makanan tinggi kalori tinggi protein, menyediakan suplemen tambahan yang dapat meningkatkan daya tahan tubuh penderita serta tidak menyediakan makanan yang dapat memicu batuk seperti makanan pedas, minuman dingin dan penyedap rasa. Dalam penelitian ini dapat disimpulkan keluarga kurang dalam memberikan dukungan instrumental bagi penderita tuberkulosis.

Dukungan penilaian/penghargaan (appraisal) terjadi lewat ungkapan penghargaan yang positif untuk individu, dorongan maju atau persetujuan dengan gagasan atau perasaan individu lain. Dalam hal ini keluarga bertindak sebagai sebuah umpan balik, membimbing dan menengahi pemecahan masalah dan sebagai sumber validator identitas keluarga. Membantu orang belajar tentang dirinya sendiri dan menjadi seseorang pada situasi yang sama atau pengalaman yang serupa, mirip dalam berbagai cara penting atau membuat perasaan dirinya didukung oleh karena berbagai gagasan dan perasaan (Friedman dalam Setiadi, 2008). Hasil penelitian ini menunjukkan dukungan penilaian/ penghargaan dengan kategori supportif sebanyak 43.2\% (19 keluarga) dan kategori nonsupportif sebanyak 56.8\% (25 keluarga). Dukungan penilaian dalam kategori nonsupportif ini ditunjukkan dengan sebanyak $25 \% \quad$ (11 keluarga) jarang memberikan motivasi pada penderita tuberkulosis untuk meningatkan asupan makanan.

Peneliti berpendapat bahwa dukungan penilaian/penghargaan meliputi membuat perasaan pasien merasa didukung dan dihargai oleh keluarga dan memberikan motivasi untuk penderita dalam memenuhi kebutuhan makan dengan tepat. Menurut peneliti penilaian keluarga terhadap penderita tuberkulosis mempengaruhi proses pengobatan. Dukungan penilaian yang positif bermanfaat untuk penderita tuberkulosis. Hasil wawancara 
menunjukkan keluarga memandang penderita tuberkulosis dapat disembuhkan dengan upaya pengobatan dan perawatan yang baik dari keluarga. Keluarga tahu bahwa penyakit tuberkulosis menular namun bukan berarti harus mengasingkan penderita, keluarga menganggap penderita membutuhkan adanya dukungan dalam perawatan terlebih pemantauan dalam minum obat agar tidak terjadi kekambuhan. Keluarga yang supportif dalam memberikan dukungan penilaian akan meningkatkan keberhasilan penyembuhan penderita tuberkulosis.

Dukungan emosional, yaitu mengkomunikasikan cinta, peduli, percaya pada anggota keluarganya. Keluarga sebagai sebuah tempat yang aman dan damai untuk istirahat dan pemulihan serta membantu penguasaan terhadap emosi. Jenis dukungan ini melibatkan ekspresi rasa simpati, peduli terhadap seseorang sehingga memberikan perasaan nyaman, membuat individu merasa lebih baik. Individu memperoleh kembali keyakinan diri, merasa dimiliki serta merasa dicintai pada saat mengalami stres. Dalam hal ini orang yang merasa memperoleh social support jenis ini akan merasa lega karena diperhatikan, mendapat saran atau kesan yang menyenangkan pada dirinya (Friedman, 1998). Perhatian emosional, setiap orang pasti membutuhkan bantuan afeksi dari orang lain, dukungan ini berupa dukungan simpatik dan empati, cinta, kepercayaan, dan penghargaan.

Berdasarkan hasil penelitian ini menunjukkan bahwa dukungan emosional dengan kategori supportif sebanyak 54.5\% (24 keluarga) dan kategori nonsupportif sebanyak 45.5\% (20 keluarga). Dukungan emosional dalam kategori nonsupportif ini ditunjukkan dengan sebanyak $18 \% \quad$ (8 keluarga) jarang menyediakan waktu untuk berkomunikasi dan berinteraksi dengan penderita tuberkulosis di rumah.

Peneliti berpendapat dukungan emosional meliputi mendiskusikan tentang keadaan penderita TBC dengan anggota keluarga lainnya untuk mencari solusi terbaik dalam peningkatan berat badan, menyediakan waktu untuk berkomunikasi dan berinteraksi dengan penderita, mendengarkan keluhan dan keinginan penderita selama sakit, dan mempercayai keputusan penderita dalam memilih makanan yang dianjurkan selama sakit. Dalam penelitian ini dukungan emosional menunjukkan masih kurang ditunjukkan dengan lebih dari setengah keluarga penderita tuberkulosis bekerja sebagai wiraswasta yaitu sebanyak 57\% (25 keluarga) dan 15,9\% (7 keluarga) bekerja sebagai Pegawai Swasta, sehingga waktu yang diberikan keluarga untuk berinteraksi dengan penderita tuberkulosis kurang. 
Padahal dukungan keluarga akan benarbenar bisa dirasakan penderita apabila ada keterlibatan dan perhatian yang mendalam dari keluarga. Dengan demikian seseorang yang menghadapi persoalan merasa dirinya tidak menanggung beban sendiri tetapi masih ada orang lain yang memperhatikan, mau mendengar segala keluhannya, bersimpati, dan empati terhadap persoalan yang dihadapinya, bahkan mau memecahkan masalah yang dihadapinya (House dalam Setiadi, 2008).

Dalam penelitian ini, peneliti berpendapat bahwa keluarga supportif dalam memberikan dukungan informasional (57\%) dan dukungan penilaian (55\%) disebabkan karena keluarga telah memiliki pengetahuan dan wawasan yang baik dalam merawat penderita tuberkulosis, serta keluarga memiliki hubungan yang kuat dalam memberikan perhatian sehingga membuat penderita tuberkulosis percaya bahwa dirinya diperhatikan atau dicintai, dianggap dan dihargai. Dalam penelitian ini hampir setengah sumber dukungan keluarga diberikan oleh istri sebanyak 36,4\% (16 keluarga). Dengan adanya dukungan keluarga yang baik ini maka keberhasilan penyembuhan dan pemulihan klien tuberkulosis akan meningkat.

\section{Kesimpulan dan Saran}

\section{Kesimpulan}

Dukungan keluarga dalam pemenuhan kebutuhan makan adalah bantuan nyata yang diberikan oleh anggota keluarga yang paling bertanggung jawab dalam memenuhi kebutuhan nutrisi sehari-hari penderita TBC Paru yang tinggal serumah. Berdasarkan hasil penelitian yang dilaksanakan di wilayah UPTD Puskesmas sekota Blitar, dukungan keluarga dalam pemenuhan kebutuhan makan penderita TBC Paru di rumah dengan kategori supportif sebanyak 59,1\% (26 keluarga) dan dengan kategori nonsupportif sebanyak 40,9\% (18 keluarga). Dari hasil penelitian yang ditinjau dari jenis dukungan keluarga dengan kategori supportif menunjukkan dukungan informasional sebanyak 57\% (24 keluarga), dukungan penilaian sebanyak 55\% (24 keluarga), dukungan instrumental 48\% (21 keluarga) dan dukungan emosional sebanyak 45\% (20 keluarga).

\section{Saran}

Adanya program khusus untuk meningkatkan dukungan keluarga dalam pemenuhan kebutuhan makan penderita tuberkulosis. 
Triana Setijaningsih, Nunung Rahayu Ningsih, Suprajitno. Dukungan Keluarga Dalam Pemenuhan Kebutuhan Makan Penderita Tbc Paru Di Rumah

\section{Referensi}

Almatsier, S. (2004). Prinsip Dasar Ilmu

Gizi. Jakarta: Gramedia Pustaka Utama.

Arikunto, S. (2006). Prosedur Penelitian Suatu Pendekatan Praktik. Jakarta: PT Rineka Cipta.

Asih, N. G. (2004). Keperawatan Medikal Bedah: Klien Dengan Gangguan Sistem Pernapasan. Jakarta: Penerbit Buku Kedokteran EGC.

Cahyono, S. B. (2014). Vaksinasi, Cara Ampuh Cegah Penyakit Infeksi. Yogyakarta: Kanisius.

Djojodibroto, D. (2009). Respirologi. Jakarta: Penerbit Buku Kedokteran EGC.

Escott-Stump, S. (2008). Nutrition and Diagnostic Related Care Ed 6. USA: Baltimore.

Friedman, M. M. (1998). Keperawatan Keluarga: Teori dan Praktik. Jakarta: EGC.

Hidayat, A. A. (2015). Pengantar Kebutuhan Dasar Manusia Edisi 2. Jakarta: Salemba Medika.

Kemenkes. (2016). Pusat Data dan Informasi Kementrian Kesehatan RI. Indonesia: Kemenkes RI.

Manalu, H. (2010). Faktor-Faktor yang Mempengaruhi Kejadian TB Paru dan Upaya Penanggulangannya. Jurnal
Ekologi Kesehatan Vol 9 No 4

Desember 2010.

Manurung, S. (2008). Gangguan Sistem Pernafasan Akibat Infeksi. Jakarta:

Trans Info Media.

Mubarak, Wahit Iqbal, dkk. (2007). Promosi Kesehatan Sebuah Pengantar Proses Belajar Mengajar dalam Pendidikan. Yogyakarta: Graha Ilmu.

Notoatmodjo, S. (2007). Kesehatan Masyarakat: Ilmu dan Seni. Jakarta: Rineka Cipta.

Nurarif, A. H. (2015). Aplikasi Asuhan Keperawatan Berdasarkan Diagnosis Medis dan Nanda Nic-Noc. Jogjakarta: Mediaction.

Nursalam. (2013). Konsep dan Penerapan Metode Penelitian Ilmu Keperawatan. Jakarta: Salemba Medika.

Rab, T. (2010). Ilmu penyakit Paru. Jakarta: Trans Info Media.

Setiadi. (2008). Konsep \& Proses Keperawatan Keluarga. Yogyakarta: Graha Ilmu.

Smeltzer, S. \& Bare, B. (2002). Keperawatan Medikal Bedah. Jakarta: Penerbit Buku Kedokteran EGC.

Sugiyono. (2010). Statistika untuk

Penelitian. Bandung: Alfabeta.

Suprajitno. (2004). Asuhan Keperawatan Keluarga: Aplikasi dalam Praktik. Jakarta: EGC. 
Triana Setijaningsih, Nunung Rahayu Ningsih, Suprajitno. Dukungan Keluarga Dalam Pemenuhan Kebutuhan Makan Penderita Tbc Paru Di Rumah

Wasis. (2008). Pedoman Riset Praktis

Untuk Profesi Perawat. Jakarta: EGC. 